\title{
Prevalence, genotypes and risk factors associated with hepatitis C virus infection in hemodialysis patients in Campo Grande, MS, Brazil
}

\author{
Solange Z Freitas, Rivaldo V da Cunha, Regina MB Martins ${ }^{1}$, \\ Sheila A Teles ${ }^{1}$, Mary L Ibanhes ${ }^{2}$, Ana RC Motta-Castro/ ${ }^{+}$
}

\begin{abstract}
Departamento de Farmácia Bioquímica, Universidade Federal de Mato Grosso do Sul, Cidade Universitária s/n, Caixa Postal 549, 79070-900 Campo Grande, MS, Brasil ' Universidade Federal de Goiás, Goiânia, GO, Brasil ²Laboratório Central de Saúde Pública, Campo Grande, MS, Brasil
\end{abstract}

A survey was conducted among the hemodialysis units of the city of Campo Grande, located in the state of Mato Grosso do Sul in the Mid-west region of Brazil, with the aim of investigating the prevalence, risk factors, and genotypes of hepatitis $C$ virus (HCV) infection. A total of 163 patients were interviewed in five dialysis units. Serum samples were screened for anti-HCV. Positive samples were tested for HCV RNA and genotyped. The prevalence of anti-HCV was $11 \%$ (95\% CI: 6.8-17.1). A history of transfusion with blood that was not screened for anti-HCV and length of time on hemodialysis were associated with HCV infection. HCV RNA was detected in 12 samples: ten were of genotype 1, subtypes $1 \mathrm{a}(75 \%)$ and $1 \mathrm{~b}(8.3 \%)$, and two were of genotype 3 , subtype 3 a (16.7\%).

Key words: hepatitis C virus - hemodialysis - prevalence - genotypes - risk factors

Approximately 170 million people are infected with hepatitis $\mathrm{C}$ virus (HCV) worldwide. This infection has been the cause of chronic hepatitis, cirrhosis, and hepatocellular carcinoma. Blood-transfused individuals and patients who have undergone invasive medical procedures such as hemodialysis have been considered to be at high risk for hepatitis $\mathrm{C}$ infection (Chen \& Morgan 2006). These patients have an increased tendency to become chronic carriers of $\mathrm{HCV}$ and also to be potential disseminators of this agent in the hemodialytic environment (Izopet et al. 2005, Hmaied et al. 2006). In addition, hepatitis $\mathrm{C}$ seems to increase the mortality rate of this group of patients (Meyers et al. 2003).

$\mathrm{HCV}$ is classified into six major genetic groups, designated genotypes 1 to 6 , each comprising multiple subtypes (designated a, b, c, etc). These genotypes have distinct geographical distributions. Genotype determination is a relevant predictive parameter of the response to antiviral treatment. Furthermore, the genotyping of $\mathrm{HCV}$ isolates is a useful tool in molecular studies carried out to establish the source of outbreaks in hemodialysis centers and other nosocomial settings (Zein 2000).

The prevalence of HCV antibodies has been reported to range from $3 \%$ in hemodialysis patients in the USA to more than $70 \%$ in Eastern Europe (Vladutiu et al. 2000, Finelli et al. 2005). In Brazil, a country of continental dimensions, HCV infection has not been fully investigated among hemodialysis patients. Some studies have found

Financial support: $\mathrm{CNPq}$

+ Corresponding author: an.castro@terra.com.br

Received 29 September 2007

Accepted 2 June 2008
HCV prevalence rates to range from $8.4 \%$ to $65 \%$ (Vanderborght et al. 1995, Mello et al. 2007). In the state of Mato Grosso do Sul, there is no data about this infection in patients undergoing hemodialysis. Therefore, this study is the first to investigate the HCV infection prevalence, risk factors, and genotypes in hemodialysis patients in the city of Campo Grande, the capital of the state of Mato Grosso do Sul in the Mid-west region of Brazil.

This investigation was carried out in the five hemodialysis units of Campo Grande, in 2003. The study sample size was calculated based on an alpha error of 5\%, an expected anti-HCV prevalence of $13 \%$ (Souza et al. 2003 ), and a precision of $5 \%$. In accordance with these data, the sample size necessary was 174 patients. Study participants were recruited using a systematic sampling method, according to the proportion of patients by unit. The protocol used in this study was approved by the Ethical Committee of the Universidade Federal de Mato Grosso do Sul. Informed consent was obtained from all participants (or their parents for children).

A total of $163(93.7 \%)$ patients participated in the study. Initially, all participants were interviewed in order to obtain sociodemographic data and risk factors associated with HCV infection. The study population ranged in age from 13 to 83 years (mean age 48 years). Ninety-seven participants (59.5\%) were males and 66 $(40.5 \%)$ were females. Most of the participants (80\%) were of low socioeconomic (families with monthly income less than US\$200) and education levels (less than eight years of formal education). All subjects received treatment three times a week and were distributed into two or three shifts depending on their dialysis unit. Hemodialysis was performed with bicarbonate and cuprophane or polysulphone dialyzers. These and the bloodlines were disinfected and reused by the same patient. Hemodialysis machines were disinfected at the end of the day, and equipment surfaces were disinfected after each session. 
Blood samples were collected from all participants, and serum samples were tested for anti-HCV by a thirdgeneration enzyme-linked immunoassay (ELISA) (Innotest HCV Ab III, Innogenetics, Ghent, Belgium). Anti-HCV reactive samples were retested by a line immunoassay (LIA) (INNO-LIA HCV Ab III, Innogenetics). Positive anti-HCV samples were submitted for RNA extraction, reverse transcription, and a nested PCR with primers complementary to the conserved area of the 5, non-coding region of HCV (Espírito-Santo et al. 2007). Positive samples were genotyped by "line probe assay" (INNO-LiPA HCV, Innogenetics NV, Ghent, Belgium).

The prevalence of infection with $95 \%$ confidence intervals $(95 \%$ CI) was calculated. Chi-square and Fisher tests were used to evaluate the risk factors associated with $\mathrm{HCV}$ infection (defined as positive for anti-HCV). Statistical significance was assessed at the 0.05 probability level in all analyses. Risk factors, first estimated by odds ratio in univariate analysis, were analyzed subsequently by multiple logistic regression. Statistical analysis was performed using Epiinfo program, version 2000 package developed by the Centers for Disease Control and Prevention (Atlanta, GA).

Of the 163 studied patients, $19(11.7 \%)$ were found to be anti-HCV positive by ELISA, and 18 were subsequently confirmed as being positive by LIA, resulting in an overall anti-HCV prevalence of $11 \%(95 \% \mathrm{CI}$ : $6.8-17.1$ ), ranging from $0 \%$ to $28.6 \%$ depending on the dialysis unit. HCV RNA was detected in 12/18 (67\%) of the anti-HCV positive patients. Ten samples were genotyped as genotype 1 , subtypes $1 \mathrm{a}(75 \%)$ and $1 \mathrm{~b}(8.3 \%)$, and two samples (16.7\%) as genotype 3 , subtype 3 a.

An analysis of the risk factors showed that a history of transfusion with blood not screened for anti-HCV (before November 1993), the length of time on hemodialysis, and having treatment in multiple units were significantly associated with $\mathrm{HCV}$ infection by univariate analysis. These factors were included in a logistic regression model, which showed that a history of transfusion with blood not screened for anti-HCV and a duration of he- modialysis greater than seven years were independently associated with $\mathrm{HCV}$ infection (Table). Interestingly, in the state of Goiás, located in the same region of Brazil, a study that investigated hepatitis B virus (HBV) infection in the hemodialysis patient population (Ferreira et al. 2006) also found that the same risk factors were independently associated with HBV infection; this implies that $\mathrm{HCV}$ is disseminated among hemodialysis patients in a similar fashion as HBV in these states.

In this investigation, the prevalence of $\mathrm{HCV}$ infection in hemodialysis patients in the city of Campo Grande was almost eight times greater than that observed in blood donors from the same region (Martins et al. 1994). Nevertheless, in comparison with other hemodialysis populations in Mid-west region of Brazil, this was similar to those found in the states of Goiás $(16.4 \%$; $95 \%$ CI: 14.3-18.7) (Carneiro et al. 2007) and Mato Grosso (16.9\%; 95\% CI: 13.3-20.8) (Santos \& Souto 2007). These findings were also in accordance with other Brazilian investigations, in which the prevalence has varied from $8.4 \%$ to $65 \%$ (Vanderborght et al. 1995, Mello et al. 2007). In contrast, this anti-HCV prevalence rate was higher than those found in investigations carried out in other countries such as Germany (7\%) (Hinrichisen et al. 2002), the US (7.8\%) (Finelli et al. 2005), Spain (6.8\%) (Gallego et al. 2006) and the UK (3\%) (Jadoul et al. 2004). However, the seroprevalence detected was lower than that of India (30\%) (Jaiswal et al. 2002), Japan (15\%) (Furusyo et al. 2001), France (30\%) and Poland (44\%) (Jadoul et al. 2004), ratifying the high prevalence of hepatitis $C$ in hemodialysis patients.

The distribution of HCV genotype in the study population, with a predominance of subtype 1a followed by $1 \mathrm{~b}$ and $3 \mathrm{a}$, differs from that of local blood donors, in which subtypes $1 \mathrm{a}$ and $1 \mathrm{~b}$ were detected equally (36.8\%), followed by $3 \mathrm{a}(21.1 \%)$ and $2 \mathrm{~b}(5.3 \%)$ (Martins et al. 2006). However, the predominance of genotype 1, subtype 1a was also found in other Brazilian studies carried out among hemodialysis patients of São Paulo (Moreira et al. 2003, Perez et al. 2003), Tocantins (Souza et al. 2003),

TABLE

Risk factors associated with hepatitis C virus (HCV) infection in hemodialysis patients in Campo Grande, Mato Grosso do Sul, Brazil

\begin{tabular}{|c|c|c|c|c|c|c|}
\hline Risk factors & $\begin{array}{c}\text { Anti-HCV } \\
\text { Positive/Total }\end{array}$ & $(\%)$ & $\begin{array}{c}\text { Crude OR } \\
(95 \% \mathrm{CI})\end{array}$ & $\mathrm{p}$ value & $\begin{array}{l}\text { Adjusted OR }{ }^{a} \\
\quad(95 \% \mathrm{CI})\end{array}$ & $\mathrm{p}$ value \\
\hline \multicolumn{7}{|c|}{ Length of time on hemodialysis } \\
\hline$<5$ years & $1 / 107$ & 0.9 & 1.0 & & 1.0 & \\
\hline $5-7$ years & $4 / 32$ & 12.5 & $15.1(1.5-370)$ & 0.01 & $10.4(0.9-125.2)$ & 0.06 \\
\hline$>7$ years & $13 / 24$ & 54.2 & $125.3(14.4-282)$ & 0.00 & $58.1(4.1-822.3)$ & 0.00 \\
\hline \multicolumn{7}{|c|}{ Treatment in multiple dialysis units } \\
\hline No & $2 / 76$ & 2.6 & 1.0 & & 1.0 & 7.43 \\
\hline Yes & $16 / 87$ & 18.4 & $8.3(1.7-54.5)$ & 0.00 & $8.3(0.8-85.0)$ & 0.07 \\
\hline \multicolumn{7}{|c|}{ Transfusion of blood screened for anti-HCV ${ }^{b}$} \\
\hline Yes & $6 / 104$ & 5.8 & 1.0 & & 1.0 & - \\
\hline No & $12 / 27$ & 44.4 & $13.1(4.3-40.1)$ & 0.00 & $12.3(1.4-103.2)$ & 0.02 \\
\hline
\end{tabular}

$a$ : adjusted for age, gender, length of time on hemodialysis, treatment in multiple dialysis units and transfusion of blood screened for anti-HCV; $b$ : the denominator represents the number of patients that received blood transfusion. CI: confidence interval; OR: odds ratio. 
Recife (Albuquerque et al. 2005) and Goiás (EspíritoSanto et al. 2007). Significantly, most patients infected with HCV subtype la were receiving treatment at the same hemodialysis unit in Campo Grande. Similarly, this genotype is also predominant among hemodialysis patients of other countries such as the United States (Chen \& Weck 2002) and Jordan (Bdour 2002).

As observed by other authors (Salama et al. 2000, Albuquerque et al. 2005, Carneiro et al. 2007), two variables were independently associated with $\mathrm{HCV}$ infection in our patients: blood transfusion before screening for anti-HCV and length of time on hemodialysis treatment. The first finding clearly demonstrates the impact of screening for anti-HCV in candidates for blood donation, while the second reinforces the notion of the hemodialytic environment as a source of HCV dissemination. In fact, patients who had previously received a blood transfusion that was not screened for anti-HCV presented a 12.3-fold greater risk of $\mathrm{HCV}$ infection when compared with those that were transfused with screened blood, but the first group constituted only a minority of the patients from this study. For the majority of HCV-infected patients who received blood transfusion screened for anti-HCV, the most probable risk factor was hemodialysis treatment. Moreover, the association between the length of time on hemodialysis and $\mathrm{HCV}$ infection, with a greater risk (58.1-fold) for patients under treatment for more than seven years when compared to those who had undergone less than five years of treatment, reinforces the probability of nosocomial transmission in the studied units.

In Brazil, infection control measures in hemodialysis units became mandatory after 1996 as consequence of new Health Ministry standards for renal units (Ministério da Saúde 1996). Although the prevalence of HCV infection found in the present investigation is still high, it was markedly lower than the alarming prevalence of $65 \%$ found in hemodialysis patients in Rio de Janeiro (Vanderborght et al. 1995) before the implementation of new rules for Brazilian renal units. In fact, this infection has declined after hemodialysis-specific infection control measures were adopted in Brazilian units (Carneiro et al. 2005). Nevertheless, the legacy of negligence has provided a significant $\mathrm{HCV}$ reservoir among chronic renal patients, who at any time may cause outbreaks of hepatitis $C$ unless stricter hygiene measures are not fully enforced.

In summary, although the prevalence of $\mathrm{HCV}$ infection in hemodialysis patients in the city of Campo Grande is similar to those recently found in other Brazilian hemodialysis units, it is still high when compared with the prevalence among blood donors from the same region. The finding that the length of time on hemodialysis is associated with anti-HCV positivity suggests nosocomial transmission. The predominance of genotype 1, subtype 1a of HCV in this population corroborates this hypothesis, reinforcing the need for stricter adherence to infection control measures in dialysis units.

\section{REFERENCES}

Albuquerque ACC, Coêlho MRCD, Lopes EPA, Lemos MF, Moreira RC 2005. Prevalence and risk factors of hepatitis C virus infection in hemodialysis patients from one center in Recife, Brazil. Mem Inst Oswaldo Cruz 100: 467-470.
Bdour S 2002. Hepatitis C virus infection in jordanian haemodialysis units: serological diagnosis and genotyping. J Med Microbiol 51: 700-704.

Carneiro MA, Teles SA, Lampe E, Espírito-Santo MP, GouveiaOliveira R, Reis NR, Yoshida CF, Martins RM 2007. Molecular and epidemiological study on nosocomial transmission of $\mathrm{HCV}$ in hemodialysis patients in Brazil. J Med Virol 79: 1325-1333.

Carneiro MAS, Teles SA, Dias MA, Ferreira RC, Naghettini AV, Silva SA, Lampe E, Yoshida CFT, Martins RMB 2005. Decline of hepatitis $\mathrm{C}$ infection in hemodialysis patients in Central Brazil: a ten years of surveillance. Mem Inst Oswaldo Cruz 100: 345-349.

Chen SL, Morgan TR 2006. The natural history of hepatitis C virus (HCV) infection. Int J Med Sci 3: 47-52.

Chen Z, Weck KE 2002. Hepatitis C virus genotyping: interrogation of the 5' untranslated region cannot accurately distinguish genotypes 1a and 1b. J Clin Microbiol 40: 3127-3134.

Espírito-Santo MP, Carneiro MAS, Reis NRS, Kozlowski AG, Teles SA, Lampe E, Yoshida CFT, Martins RMB 2007. Genotyping hepatitis $\mathrm{C}$ virus from hemodialysis patients in Central Brazil by line probe assay and sequence analysis. Braz J Med Biol Res 40: 545-550.

Ferreira RC, Teles SA, Dias MA, Tavares VR, Silva SA, Gomes SA, Yoshida CFT, Martins RMB 2006. Hepatitis B virus infection profile in hemodialysis patients in Central Brazil: prevalence, risk factors, and genotypes. Mem Inst Oswaldo Cruz 101: 689-692.

Finelli L, Miller JT, Tokars JI, Alter MJ, Arduino MJ 2005. National surveillance of dialysis-associated diseases in the United States, 2002. Semin Dial 18: 52-61.

Furusyo N, Hayashi J, Kakuda K, Ariyama I, Tanaka YK, Shimizu C, Etoh Y, Shigematsu M, Kashiwagi S 2001. Acute hepatitis $\mathrm{C}$ among Japanese hemodialysis patients: a prospective 9-year study. Am J Gastroenterol 96: 1592-1600.

Gallego E, López A, Pérez J, Llamas F, Lorenzo I, López E, Illescas ML, Andrés E, Olivas E, Gómez-Roldan C 2006. Effect of isolation measures on the incidence and prevalence of hepatitis $\mathrm{C}$ virus infection in hemodialysis. Nephron Clin Pract 104: c1-c6

Hinrichsen H, Leimenstoll G, Stegen G, Schrader H, Folsch UR, Schmidt WE 2002. Prevalence and risk factors of hepatitis C virus infection in haemodialysis patientes: a multicentre study in 2796 patients. Gut 51: 429-433.

Hmaied F, Ben Mamou M, Saune-Sandres K, Rostaing L, Slim A, Arrouji Z, Ben Redjeb S, Izopet J 2006. Hepatitis C virus infection among dialysis patients in Tunisia: incidence and molecular evidence for nosocomial transmission. J Med Virol 78: 185-191.

Izopet J, Sandres-Saune K, Kamar N, Salama G, Dubois M, Pasquier C, Rostaing L 2005. Incidence of HCV infection in French hemodialysis units: a prospective study. J Med Virol 77: 70-76.

Jadoul M, Poignet JL, Geddes C, Locatelli F, Medin C, Krajewska M, Barril G, Scheuermann E, Sonkodi S, Goubau P 2004. The changing epidemiology of hepatitis $\mathrm{C}$ virus $(\mathrm{HCV})$ infection in haemodialysis: European multicentre study. Nephrol Dial Transplant 19: 904-909.

Jaiswal SB, Chitnis DS, Salgia P, Sepaha A, Pandit CS 2002. Prevalence of hepatitis viruses among chronic renal failure patients on hemodialysis in central India. Dial Transplant 31: 234-240.

Martins RM, Vanderborght BO, Rouzere CD, Santana CL, Mori DN, Ferreira RG, Yoshida CF 1994. Anti-HCV related to HCV PCR and risk factors analysis in a blood donor population of central Brazil. Rev Inst Med Trop Sao Paulo 36: 501-506. 
Martins RMB, Teles SA, Freitas NR, Motta-Castro ARC, Souto FJD, Mussi A, Amorim RMS, Martins CRF 2006. Distribution of hepatitis $\mathrm{C}$ virus genotypes among blood donors from Mid-west region of Brazil. Rev Inst Med Trop Sao Paulo 48: 53-55.

Mello LA, Melo-Junior MR, Albuquerque ACC, Coelho MRCD 2007. Soroprevalência da hepatite $\mathrm{C}$ em pacientes hemodialisados. Rev Soc Bras Med Tropical 40: 290-294.

Meyers C, Seeff LB, Stehman-Breen C, Hoofnagle JH 2003. Hepatitis $\mathrm{C}$ and renal disease: an update. Am J Kidney Dis 41: 631-657.

Ministério da Saúde 1996. Portaria 2042. Diário Oficial da União, Brasília, Brasil.

Moreira R, Pinho JRR, Fares J, Oba IT, Cardoso MR, Saraceni CP, Granato C 2003. Prospective study of hepatitis C virus infection in hemodialysis patients by monthly analysis of HCV RNA and antibodies. Can J Microbiol 49: 503-507.

Perez RM, Ferraz ML, Figueiredo MS, Contado D, Koide S, Ferreira AP, Cendoroglo Neto M, Medina Pestana JO, Silva AE 2003. Unexpected distribution of hepatitis $\mathrm{C}$ virus genotypes in patients on hemodialysis and kidney transplant recipients. J Med Virol 69: 489-494.
Salama G, Rostalng L, Sandres K, Izopet J 2000. Hepatitis C virus infection in French Hemodialysis units: a multicenter study. J Med Virol 61: 44-51.

Santos MAM, Souto FJD 2007. Infection by the hepatitis C virus in chronic renal failure patients undergoing hemodialysis in Mato Grosso state, Central Brazil: a cohort study. BMC Public Health 7: 32

Souza KP, Luz JA, Teles SA, Carneiro MAS, Oliveira LA, Gomes AS, Dias MA, Gomes SA, Yoshida CFT, Martins RMB 2003. Hepatitis $\mathrm{B}$ and $\mathrm{C}$ in the hemodialysis unit of Tocantins, Brazil: serological and molecular profiles. Mem Inst Oswaldo Cruz 98: 599-603.

Vanderborght BO, Rouzere C, Ginuino CF, Maertens G, Van Heuverswyn H, Yoshida CF 1995. High prevalence of hepatitis C infection among Brazilian hemodialysis patients in Rio de Janeiro: a oneyear follow-up study. Rev Inst Med Trop São Paulo 37: 75-79.

Vladutiu DS, Cosa A, Neamtu A, State D, Braila M, Gherman M, Patiu IM, Dulau-Florea I 2000. Infections with hepatitis $B$ and $C$ viruses in patients on maintenance dialysis in Romania and in former communist countries: yellow spots on a blank map? $J$ Viral Hepat 7: 313-319.

Zein NN 2000. Clinical significance of hepatitis C virus genotypes. Clin Microbiol Rev 13: 223-235. 